\title{
SUSTAINABLE ECONOMIC DEVELOPMENT OF AGRITOURISM BASED ON THE EXAMPLE OF THE NORTH KAZAKHSTAN REGION
}

\author{
СОЛТҮСТІК ҚАЗАҚСТАН ОБЛЫСЫ МЫСАЛЫНДА АГРОТУРИЗМ \\ ЭКОНОМИКАСЫНЫҢ ТҰРАҚТЫ ДАМУЫ
}

\section{УСТОЙЧИВОЕ РАЗВИТИЕ ЭКОНОМИКИ АГРОТУРИЗМА НА ПРИМЕРЕ СЕВЕРО-КАЗАХСТАНСКОЙ ОБЛАСТИ}

\author{
D.N. SHAIKIN* \\ C.E.Sc., Professor \\ D.O. ABUTALIP \\ Ph.D student \\ A.ZH. BEKMATOVA \\ Ph.D student \\ M. Kozybayev North Kazakhstan University, Petropavlovsk, Kazakhstan \\ *corresponding author e-mail: shaikindimash@mail.ru \\ Д.Н. ШАЙКИН* \\ э.Ғ.к., профеессор \\ Д.О. әБУТәлІп \\ Ph.D докторанты \\ А.Ж. БЕКМАТОВА \\ Ph.D докторанты \\ М. Қозыбаев атындағы Солтүстік-Қазақстан университеті, Петропавл, Қазақстан \\ *автордың электрондық поштасы: shaikindimash@mail.ru \\ Д.Н. ШАЙКИН* \\ К.Э.Н, профрессор \\ Д.О. ӘБУТӘЛІП \\ докторант Ph.D \\ А.Ж. БЕКМАТОВА \\ докторант Ph.D \\ Северо-Казахстанский университет им. М. Козыбаева, Петропавловск, Казахстан \\ *электронная почта автора: shaikindimash@mail.ru
}

\begin{abstract}
As the goal of the study, one of the relevant modern problems of rural areas of the Republic of Kazakhstan is noted - ensuring sustainable economic development of agritourism, which should become one of the key drivers of the regional economy. Objectives - to study aspects of sustainable agricultural tourism based on the example of the North Kazakhstan region. Results - the scientific points of view of Kazakhstani and foreign authors, offering solutions to issues related to the efficiency and feasibility of agritourism ecosystem are presented; key indicators and methodological approaches to assess the promotion of agritourism are identified; a matrix of the main directions for further expansion of the tourism industry in North Kazakhstan was developed; econometric dependences reflecting the dynamics of the number of agrotourists in the region in 2016-2020 are shown. Based on the calculation of autocorrelation coefficient of the residuals and the average approximation error, a conclusion was made about the optimal use of the constructed dependencies in the economy in order to ensure the sustainable development of agricultural tourism sector in the region. The research methodology is associated with the analysis that characterizes the introduction and acquaintance with the peculiarities of rural life, the activities of peasant farms. In the opinion of the authors, the conclusions will largely help to achieve the stated goals and objectives. Researchers are convinced that particularly rural tourism business that should become one of the main imperatives for the development of a modern village in the republic, contributing to a sustainable increase in the quality and standard of living of the population living in rural areas, raising the balance of payments and total exports, and increasing employment of rural residents, ensures food security of the country.
\end{abstract}

Agricultural policy: mechanism of implementation 


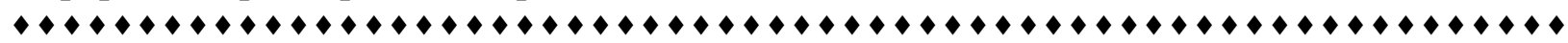

Аңдатпа. Зертmеудің мақсаты ретінде Қазақстан Республикасының ауылдық аумақтарының өзекті қазіргі проблемаларының бірі - агротуризмнің тұрақты экономикалық дамуын қамтамасыз ету, ол өңір экономикасының негізгі драйверлерінің бірі болуы тиіс. Міндеттері - Солтүстік Қазақстан облысы үлгісінде тұрақты Ауыл шаруашылығы туризмінің аспектілерін зерделеу. Нәтижелері - агротуристік экожүйенің тиімділігі мен мақсаттылығына байланысты мәселелерді шешуді ұсынатын қазақстандық және шетелдік авторлардың ғылыми көзқарастары ұсынылған; агротуризмнің ілгерілеуіне баға беруге мүмкіндік беретін негізгі көрсеткіштер мен әдіснамалық тәсілдер айқындалған; Сқо-да туристік индустрияны одан әрі таратудың негізгі бағыттарының матрицасы әзірленген; 2016-2020 жылдары облыстағы агротуристер санының серпінін көрсететін эконометрикалық тәуелділіктер көрсетілген. Қалдықтардың автокорреляциясы коэффрициентін және жуықтаудың орташа қатесін есептеу негізінде аймақтағы аграрлық туризм саласының тұрақты дамуын қамтамасыз ету мақсатында экономикада салынған тәуелділіктерді пайдаланудың оңтайлылығы туралы қорытынды жасалған. Зерттеу әдістемесі ауыл өмірінің ерекшеліктерімен, шаруа қожалықтарының қызметімен танысуды сипаттайтын талдаумен байланысты. Авторлардың пікірінше, қорытындылар көп жағдайда осы мақсаттар мен міндеттерді жүзеге асыруға мүмкіндік береді. Зерттеушілер ауылдық туристік бизнес ауылдық жерлерде тұратын халықтың өмір сүру сапасы мен деңгейінің тұрақты өсуіне ықпал ететін, төлем балансын және жиынтық экспортты көтеретін, ауылдық елді мекендер тұрғындарының жұмыспен қамтылуын ұлғайтатын, елдің азық-түлік қауіпсіздігін қамтамасыз ететін республикадағы қазіргі заманғы ауылды дамытудың негізгі императивтерінің бірі болуға тиіс екеніне сенімді.

Аннотация. В качестве цели исследования отмечается одна из актуальных современных проблем сельских территорий Республики Казахстан - обеспечение устойчивого экономического развития агротуризма, который должен стать одним из ключевых драйверов экономики региона. Задачи - изучение аспектов стабильного сельскохозяйственного туризма на примере Северо-Казахстанской области. Результаты - представлены научные точки зрения казахстанских и зарубежных авторов, предлагающих решение вопросов, связанных с эффективностью и целесообразностью агротуристской экосистемы; определены ключевые показатели и методологические подходы, позволяющие дать оценку продвижению агротуризма; разработана матрица основных направлений дальнейшего распространения туристической индустрии в СКО; показаны эконометрические зависимости, отражающие динамику количества агротуристов в области в 2016-2020гг. На основе расчета коэффициента автокорреляции остатков и средней ошибки аппроксимации сделано заключение об оптимальности использования построенных зависимостей в экономике с целью обеспечения устойчивого развития сферы аграрного туризма в регионе. Методология исследования связана с анализом, характеризующим приобщение и знакомство с особенностями сельского быта, деятельностью крестьянских хозяйств. По мнению авторов, выводы во многом позволят реализовать указанные цели и задачи. Исследователи убеждены в том, что именно сельский туристический бизнес должен стать одним из основных императивов развития современного села в республике, способствующих устойчивому росту качества и уровня жизни населения, которое проживает в сельской местности, поднимает платежный баланс и совокупный экспорт, увеличивает занятость жителей сельских населенных пунктов, обеспечивает продовольственную безопасность страны.

Түйінді сөздер: агротуризм экономикасы, ауылдық аумақтар, туризм саласындағы мемлекеттік бағдарламалар, сапасы, өмір сүру деңгейі, ауыл халқы, жұмыспен қамту.

Key words: economics of agritourism, rural areas, State programs in the field of tourism, quality, standard of living, rural population, employment.

Ключевые слова: экономика агротуризма, сельские территории, государственные программы в сфере туризма, качество, уровень жизни, сельское население, занятость.

Introduction. Analysis of the state and assessment of the dynamics of sustainable development of the agritourism economy is one of the key imperatives of any country. The development of this economic direction in our country is dictated by the presence of demand and supply for tourist services, which can be organized and provided on the basis of any peasant farm. These services may include demonstration of activities (shearing sheep and wool production, preparation of national dishes and drinks), instilling and mastering the practi- 
cal skills in caring for animals, farming lessons, including planting, growing, harvesting, etc.

The demand for these tourist products may be dictated by the desire to learn about the culture and way of life of people, combining this with the development of gastronomic, ethnographic, historical and archaeological knowledge that can be obtained during an agritourism tour. On the other hand, the development of agritourism should provide a socio-economic effect aimed at its popularizing, creating new jobs in rural areas and, accordingly, increasing the incomes of peasants.

A number of scientific works reflect various theoretical and methodological approaches to the study of the economy of agritourism and the implementation of its forms in the regions of our country. Some authors identify the main patterns of the formation of ethnovillages, which are the driving forces of sustainable economic development of tourist destinations in Kazakhstan [1].

Other researchers consider the applied aspects of the development of agritourism from the position of increasing the income and cultural level of the local population, the development of markets and infrastructure of the territory [2].

We can agree with the point of view of researchers who are engaged in substantiating the importance of using the mechanism of public-private partnership in the development of non-agricultural sectors of the rural economy based on the functioning of the tourism industry, which in this case acts as a diversifying economic driver [3].

Noteworthy is the theoretical analysis of the world experience in the development of rural tourism on the example of a number of such highly developed countries as the USA, Australia, Canada and England [4].

Materials and methods of research. In the scientific literature, there are a number of approaches to the study of the methodology of sustainable economic development of agritourism from the position of studying and analyzing its main types and directions.

For example, a number of authors, guided by the main preferences of consumers, distinguish the following groups of agritourism: rural (village) tourism; ecological tourism; ethnographic tourism; gastronomic (culinary) tourism; abiotic tourism; nature-based tourism (geotourism); out-of-town tourism [5].

In the methodology of researching agritourism, such symbiotic areas as agrarian medical tourism can also be distinguished; agrarian historical tourism; agrarian ecological tourism (green tourism); agricultural sports tourism; agrarian educational tourism; agricultural tourism; folklore agrarian tourism; agrarian international tourism [6].

With regard to our country, the Kazakhstan Association of Agro and Rural Tourism notes that the ecosystem of agritourism in our country began to develop relatively recently.

For example, near the city of Almaty, in the village of Aymen, there is a farm "Fauna", which grows ostriches. Tourist excursions around the farm are organized, dishes from ostrich meat and ostrich eggs are offered, ostrich feathers are sold as souvenirs. In the Zhambyl region, the "Shaushen" peasant farm in the Ryskulovsky region is engaged in kumis therapy. Here tourists can take part in the milking of mares and the production of kumis, and then purchase the products. In the Akmola region, near the village of Konstantinovka, agritourists can visit an apiary, where they are given a master class on caring for beehives, extracting honey, lighting a samovar on cones and brewing tea with berries and herbs [7].

In general, the authors of the article are convinced that most types of agrotourism activities can be successfully implemented in the so-called developing ethno-villages. Its number grows every year on the territory of Kazakhstan. Among them are "Nauryz", "Huns", "Kogez", "Zhailau", "Alash", "Nur-Sultan Ethno Fest" and others. They hold demonstrations of rituals, master classes on crafts and cooking of the national dishes, theatrical performances.

Results and their discussion. At the same time, within the framework of the methodology for researching sustainable economic development of agritourism, an important aspect is the assessment of strategic investments based on forecasting the gross regional product, its growth rates, the share of tourism in the regional economy, the dynamics of the volume of tourist services, the return on assets of tourist organizations [8].

Based on the application of the methodology of factor analysis of tourism entrepreneurship in Kazakhstan, a number of researchers identify the most significant factors affecting the level of development of business activity in the tourism sector of Kazakhstan [9].

Agreeing with these scientific positions, the authors of the article believe that when analyzing the provision of sustainable economic development in the sphere of agritourism for any region of the Republic of Kazakhstan, an appropriate matrix of the main directions of agritourism should be developed.

For the North Kazakhstan region, this developed author's matrix is shown in table 1. 
Table 1 - Matrix of the main directions of sustainable development of agritourism in the North Kazakhstan region

\begin{tabular}{|l|l|}
\hline $\begin{array}{l}\text { The direction of the development of } \\
\text { agritourism in Kazakhstan }\end{array}$ & \multicolumn{1}{|c|}{ Agritourism objects in Kazakhstan } \\
\hline $\begin{array}{l}\text { Agritourism based on the proximity } \\
\text { of the countryside to the city }\end{array}$ & $\begin{array}{l}\text { Villages of the North Kazakhstan region, close to the city of Pet- } \\
\text { ropavlovsk (Beskol, Peterfeld, etc.) }\end{array}$ \\
\hline $\begin{array}{l}\text { Agritourism based on natural land- } \\
\text { scape zones }\end{array}$ & $\begin{array}{l}\text { Resort and sanatorium zones (in the villages of Imantau and } \\
\text { Andreevka: Menkeser Island, etc.) }\end{array}$ \\
\hline $\begin{array}{l}\text { Agritourism based on the develop- } \\
\text { ment of rural agriindustry }\end{array}$ & $\begin{array}{l}\text { Agritourism on a dairy farm or horse farm (LLP "Mambetov and } \\
\text { K", PF "Arkalyk") }\end{array}$ \\
\hline $\begin{array}{l}\text { Agritourism based on historical and } \\
\text { archaeological sites }\end{array}$ & $\begin{array}{l}\text { The development of agritourism in the vicinity of the archaeolog- } \\
\text { ical excavations of the Botay culture, the settlement of Ak-Iriy, } \\
\text { Kyzyl oba and the village of Madeniet with the memorial com- } \\
\text { plex "Karasai and Agyntai Batyrs" }\end{array}$ \\
\hline $\begin{array}{l}\text { Agritourism based on the ethnocul- } \\
\text { tural development of the village }\end{array}$ & $\begin{array}{l}\text { Development of agritourism in the style of ethno-auls (in the } \\
\text { villages of Aiyrtau, Kishkenekol, etc.) }\end{array}$ \\
\hline $\begin{array}{l}\text { Agritourism based on the develop- } \\
\text { ment of scientific and technological } \\
\text { progress }\end{array}$ & $\begin{array}{l}\text { Agritourism based on specialized scientific and technical parks } \\
\text { (LLP "Zenchenko and K") }\end{array}$ \\
\hline $\begin{array}{l}\text { Agritourism based on medical and } \\
\text { wellness procedures }\end{array}$ & Agritourism based on treatment with mare's milk and kumis \\
\hline
\end{tabular}

The practical use of this matrix is supplemented by a methodology for calculating indicators characterizing the development of the agritourism sphere, which can be the number of accommodations served by visitors for travel purposes.

Table 2 provides information on the dynamics of this indicator in the districts of the North Kazakhstan region in 2016-2020.

Table 2 - Visitors served by places of accommodation by purpose of travel in the districts of the North Kazakhstan region in 2016-2020

\begin{tabular}{|l|r|r|r|r|r|}
\hline \multicolumn{1}{|c|}{ Region } & \multicolumn{1}{c|}{ people } \\
\hline North-Kazakhstan region & 91016 & 2017 & \multicolumn{1}{c|}{2018} & 2019 & 2020 \\
\hline Petropavlovsk city & 54503 & 89847 & 126740 & 144456 & 102632 \\
\hline Aiyrtau & 4952 & 5934 & 85195 & 88923 & 61795 \\
\hline Akzhar & 2425 & 2041 & 27049 & 18764 & 22911 \\
\hline M. Zhumabayev & 463 & 857 & 1161 & 2224 & 1764 \\
\hline Esil & 3266 & 2280 & 2337 & 2314 & 1235 \\
\hline Zhambyl & 1212 & 1302 & 1273 & 1226 & 819 \\
\hline Kyzylzhar & 14009 & 9032 & 11945 & 16409 & 4973 \\
\hline Mamlyut & 949 & 1055 & 945 & 794 & 17 \\
\hline Shal Akyn & 1969 & 1864 & 2449 & 2233 & 1545 \\
\hline Akkain & 674 & 808 & 450 & 802 & 15 \\
\hline Tayinsha & 2616 & 1604 & 1023 & 1247 & 1409 \\
\hline Timiryazev & 720 & 666 & 771 & 697 & 801 \\
\hline Ualikhanov & 656 & 851 & 1624 & 2103 & 785 \\
\hline G. Musrepov & 2602 & 3383 & 4735 & 5621 & 4087 \\
\hline \multicolumn{7}{|c|}{ Source: $[10]$} & \multicolumn{7}{|l}{} \\
\hline
\end{tabular}

As can be seen from table 2 , the value of the indicator in 2020 was 102632 people, which is 41824 people (or $28,95 \%$ ) less than in 2019 and 24108 people (or 19,02\%) less than in 2018 year.

The decrease in the number of visitors served by accommodations for travel purposes by area in 2020 arose in connection with the development of the COVID-19 pandemic.
According to the authors' selective survey, about $9 \%$ of the North Kazakhstanis noted that they participated in events related to the field of rural tourism and attributed by the authors to the events of the agritourism sphere.

Thus, the dynamic row for the analysis and forecasting of the indicator under consideration is presented in table 3 . 
Table 3 - The number of agritourists in the North Kazakhstan region in 2016-2020

\begin{tabular}{|c|c|c|c|c|c|}
\hline Region & 2016 & 2017 & 2018 & 2019 & 2020 \\
\hline North-Kazakhstan region & 8191 & 10876 & 11406 & 13001 & 9237 \\
\hline
\end{tabular}

Let's construct statistical equations describing the time series. As functions, the authors have chosen a linear, parabolic, exponential function, and a logarithmic parabola.

We will also select the best trend equation based on the determination of the statistical autocorrelation coefficients of the residuals ( $r$, proposed by M. Ezekiel and K. Fox) and MAPE - the middle average approximation error. The smaller the values of these coefficients, the better the equation of the corresponding trend describes the dynamics of the studied indicator and, thus, the development of the described process is more stable and suitable for economic analysis and modeling.

The autocorrelation coefficient of the residuals $(r)$ is determined as follows:

$$
\mathrm{r}=\frac{\sum 1_{\mathrm{x}} \cdot 1_{\mathrm{x}-1}}{\sum\left(1_{\mathrm{x}}\right)^{2}}
$$

where $\mathrm{I}_{\mathrm{x}}=\mathrm{y}_{\mathrm{x}}-\hat{\mathrm{y}}_{\mathrm{x}}$. In this case, $\mathrm{y}_{\mathrm{x}}-$ the actual values of the considered indicator; period.

$\hat{y}_{x}-$ values of the function in the forecast
The values of this coefficient must be within the following limits: $-1 \leq r \leq+1$. The smaller its absolute value, the better the equation describes the given sample. That is, the smaller the autocorrelation coefficient of the residuals, the more the trend equation is suitable for statistical analysis and modeling.

MAPE is determined by the following formula:

$$
\text { MAPE }=\frac{1}{\mathrm{n}} \cdot \sum\left|\frac{\mathrm{y}_{\mathrm{x}}-\hat{\mathrm{y}}_{\mathrm{x}}}{\mathrm{y}_{\mathrm{x}}}\right| \cdot 100
$$

The smaller the value of this coefficient, the better the corresponding equation describes the considered sample.

The final calculations to determine the parameters of offered models, as well as the coefficients $r$ and MAPE, are shown in table 4.

According to the calculations, the most optimal function describing the sustainable development of the number of agritourists in the regional economy is the logarithmic parabola, since the values of the coefficients $r$ and MAPE are the smallest in comparison with other functions.

Table 4 - Optimal analytical descriptive functions and their statistical characteristics for the dynamics of the number of agritourists

\begin{tabular}{|c|c|c|c|c|}
\hline \multirow{2}{*}{ № } & \multicolumn{2}{|c|}{ Optimal analytical descriptive function } & \multicolumn{2}{c|}{$\begin{array}{c}\text { Statistical } \\
\text { characteristics }\end{array}$} \\
\cline { 2 - 5 } & General form & Actual view & $\mathrm{R}$ & MAPE \\
\hline 1 & $\mathrm{y}=\mathrm{a}+\mathrm{b} \cdot \mathrm{x}$ & $\mathrm{y}=421,7 \cdot \mathrm{x}+9277,1$ & $-0,64$ & 14,37 \\
\hline 3 & $\mathrm{y}=\mathrm{a}+\mathrm{b} \cdot \mathrm{x}+\mathrm{c} \cdot \mathrm{x}^{2}$ & $\mathrm{y}=3360+5492,99 \cdot \mathrm{x}-845,21 \cdot \mathrm{x}^{2}$ & $-0,63$ & 4,89 \\
\hline 4 & $\mathrm{y}=\mathrm{a} \cdot \mathrm{b}^{\mathrm{x}}$ & $\mathrm{y}=9177,43 \cdot 1,043^{\mathrm{x}}$ & $-0,69$ & 14,58 \\
\hline 8 & $\mathrm{y}=\mathrm{a} \cdot \mathrm{b}^{\mathrm{x}} \cdot \mathrm{c}^{\mathrm{x}^{2}}$ & $\mathrm{y}=5119,6 \cdot 1,72^{\mathrm{x}} \cdot 0,92^{\mathrm{x}^{2}}$ & $-0,63$ & 4,43 \\
\hline
\end{tabular}

\section{Conclusions}

The article discusses various theoretical and methodological approaches of Kazakhstani and foreign authors to the study of the economy of agritourism and the implementation of its forms in the regions of our country.

Classification of services provided in the field of agritourism has been formulated and given, which, on the one hand, can include recreation in order to improve and satisfy the cognitive interests of the agritourist, and, on the other hand, the possibility of observing production processes and participating in farming activities.
Based on the study of scientific and methodological literature, the author's matrix of the main directions of sustainable development of agritourism in the North Kazakhstan region is presented.

The dynamics of the number of visitors served by the places of accommodation according to the purposes of travel in the context of districts was analyzed and the share of agritourists was determined on the basis of the survey.

Statistical models describing the sustainable development of the number of agritour- 
ists in the economy of the North Kazakhstan region have been determined.

In general, the authors note that the obtained theoretical and methodological results of the study may be taken into account by the public administration of the tourism sector in the development and implementation of programs for sustainable economic development aimed at improving the level and quality of life of people living in rural areas.

\section{References}

[1] Тлеубаева, А.Т. Этноаулы как один из факторов устойчивого развития туристских дестинаций в Казахстане / А.Т. Тлеубаева, А.Б. Маулен // Региональные проблемы преобразования экономики.-2019.-№8.-С.210-219.

[2] Нурулы, Е. Прикладные аспекты развития агротуризма в Западно-Казах-станской области Республики Казахстан / Е. Нурулы, А.С. Актымбаева // Научный ре-зультат. Технологии бизнеса и сервиса. - 2017. - Т.3.№3. - C.41-52.

[3] Солтангазинов, А.Р. Государственночастное партнерство в создании региональных туристических кластеров / А.Р. Солтангазинов, Б.М. Серикбаева, Г.К. Исено-ва // Проблемы агрорынка.- 2020. -№1. - С. 53-60.

[4] Мамраева, Д.Г. Мировой опыт развития сельского туризма / Д.Г. Мамраева, 3.Н. Борбасова, Л.В. Ташенова // Проблемы агрорынка. - 2019.-№2. - С.108-115.

[5] Косенчук О.В., Блинов О.А., Новиков Ю.И., Рабканова М.А. Понятие агротуризма в теории и практике управления сельскими территориями // Современные проблемы науки и образования [Электронный ресурс]. 2015.- URL: https://www.science-education.ru/ ru/ article/view?id=21435 (дата обращения: 21.05.2021).

[6] Боголюбова, С.А. Виды и тенденции развития туризма: учеб. пособие для вузов / С.А. Боголюбова. - М.: Изд-во «ЮРАЙТ», 2020. - 231c.

[7] Ешенкулова, Г.И. Привлечение туристов в сельский туризм в регионах Казахстана / Г.И. Ешенкулова, Р.Е. Агыбетова, А.С. Омарова, А.Г. Гиззатжанова //Молодежный сборник научных статей «Научные стремления». - 2018. - №24. - С.106-112.

[8] Титков, А.А. Современное экономическое состояние туристской отрасли Павлодарской области и оценка стратегических инвестиций в ее развитие / А.А. Титков, С.Ж. Ибраимова, М.М. Бегентаев, С.К. Кунязова // Экономика: стратегия и практика. - 2021.№16(1). - С. 81-92.

[9] Тлеубердинова, А.Т. Факторный анализ развития туристского предпринимательства в Казахстане / А.Т. Тлеубердинова, Ж.М. Шаекина, Д.М. Салауатова, S. Pratt //
Экономика: стратегия и практика. - 2020. №15(1). - С. 89-99.

[10] Статистика туризма. О деятельности мест размещения в Северо-Казахстанской области за 12 месяцев 2016, 2017, 2018, 2019, 2020 гг. Бюро национальной статистики Агентства по стратегическому планированию и реформам Республики Казахстан [Электронный ресурс].-2016-2020.- URL:http://www. stat.gov.kz (дата обращения: 20.05.2021).

\section{References}

[1] Tleubaeva, A.T. \& Maulen, A.B. (2019). Etnoauly kak odin iz faktorov ustojchivogo razvitiya turistskih destinacij v Kazahstane [EthnoAuls as one of the factors of sustainable development of tourist destinations in Kazakh-stan]. Regional'nye problemy preobrazovaniya ekonomiki - Regional problems of economic transformation, 8, 210-219 [in Russian].

[2] Nuruly, E. \& Aktymbayeva A.S. (2017). Prikladnye aspekty razvitiya agroturizma $\vee$ Zapadno-Kazakhstanskoi oblasti Respubliki Kazakhstan [Applied aspects of agro-tourism development in the West Kazakhstan region of the Republic of Kazakhstan]. Nauchnyi rezul'tat. Technologii biznesa i servisa - Scientific result. Business and service technologies, 3, (3), 41-52 [in Russian].

[3] Soltangazinov, A.R., Serikbayeva, B.M. \& Issenova, G.K. (2020). Gosudarstvennochastnoe partnerstvo $v$ sozdanii regional'nyh turisticheskih klasterov [Public-private partnership in the creation of regional tourism clusters]. Problemy agrorynka - Problems of Agrimarket, 1, 53-60 [in Russian].

[4] Mamraeva, D.G., Borbasova Z.N. \& Tashenova L.V. (2019). Mirovoi opyt razvitiya sel'skogo turizma [World experience in the development of rural tourism]. Problemy agrorynka Problems of Agrimarket, 2, 108-115 [in Russian].

[5] Kosenchuk, O.V., Blinov, O.A., Novikov, U.I. \& Rabkanova, M.A. (2015). Ponyatie agroturizma $\vee$ teorii i praktike upravleniya sel'skimi territoriyami [The concept of agrotourism in the theory and practice of rural territories management].- 2015.- Available at: https://www. science-education.ru/ru/article/view?id=21435 (date of access: 21.05.2021) [in Russian].

[6] Bogolubova, S.A. (2020). Vidy i tendentcii razvitiya turizma [Types and trends of tourism development]. M.: Izd-vo «URAIT». 231 p. [in Russian].

[7] Eshenkulova, G.I., Agybetova R.E., Omarova A.S. \& Gizzatzhanova A.G. (2018). Privlechenie turistov $v$ sel'skii turizm $v$ regionah Kazakhstana [Attraction tourists to rural tourism in the regions of Kazakhstan]. Molodezhnyj sbornik nauchnyh statej «Nauchnye stremleniya» - Youth collection of scientific articles «Scientific aspirations», 24, 106-112 [in Russian]. 
[8] Titkov, A.A., Ibraimova, S.Zh., Begentayev, M.M. \& Kunyazova S.K. (2021). Sovremennoe ekonomicheskoe sostoyanie turistskoj otrasli Pavlodarskoj oblasti i ocenka strategicheskih investicij $v$ ee razvitie [The current economic state of the tourism industry of the Pavlodar region and the assessment of strategic investments in its development]. Ekonomika: strategiya i praktika - Economics: strategy and practice, 16(1), 81-92 [in Russian].

[9] Tleuberdinova, A.T., Shaekina, Zh.M., Salauatova, D.M. \& Pratt, S. (2020) Faktornyi analiz razvitiya turistskogo predprinimatel'stva $v$ Kazakhstane [Factor analysis of the development of tourism entrepreneurship in Kazakhstan]. Ekonomika: strategiya i praktika - Eco- nomics: strategy and practice, 15(1), 89-99 [in Russian].

[10] Statistika turizma. O deyatel'nosti mest razmeshcheniya $v$ Severo-Kazahstanskoj oblasti za 12 mesyacev 2016, 2017, 2018, 2019, 2020 gg. Byuro nacional'noj statistiki Agentstva po strategicheskomu planirovaniyu i reformam Respubliki Kazahstan [Tourism statistics. About the activities of placement sites in the North Kazakhstan region for 12 months of 2016, 2017, 2018, 2019, 2020 Bureau of National Statistics of the Agency for Strategic Planning and Reforms of the Republic of Kazakhstan]. - 20162020 - Available at: http://www.stat.gov.kz (date of access: 20.05.2021) [in Russian].

\section{Information about authors:}

Shaikin Dinmukhammed Nurlanovich - The main author; Candidate of Economic Sciences, Professor; Head of the Department "Economics and Accounting"; M. Kozybayev North Kazakhstan University; 150000 Pushkin str.,86, Petropavlovsk, Kazakhstan; e-mail: shaikindimash@mail.ru; https://orcid.org/0000-0001-7611-2787

Abutalip Daniayr Oraltaiuly; Ph.D student; Teacher of the Department "Economics and Accounting"; M. Kozybayev North Kazakhstan University; 150000 Pushkin str., 86, Petropavlovsk, Kazakhstan; e-mail: shaikindimash@mail.ru; https://orcid.org/0000-0001-8922-2803.

Bekmatova Azhar Zhomartovna; Ph.D student; Teacher of the Department "Economics and Accounting"; M. Kozybayev North Kazakhstan University; 150000 Pushkin str., 86, Petropavlovsk, Kazakhstan; email: shaikindimash@mail.ru; https://orcid.org/0000-0002-6437-455X.

\section{Авторлар туралы ақпарат:}

Шайкин Динмухаммед Нурланович - негізгі автор; экономика гылымдарының кандидаты, профессор; "Экономика және есеп" кафедрасының меңгерушісі; М. Қозыбаев атындағы Солтүстік Қазақстан университеті; 150000 Пушкин көш., 86, Петропавл қ., Қазақстан; e-mail: shaikindimash@mail.ru; https://orcid.org/0000-0001-7611-2787

Әбутәліп Данияр Оралтайұлы; Ph.D докторанты; "Экономика және есеп" кафедрасының оқытушысы; М. Қозыбаев атындағы Солтүстік Қазақстан университеті; 150000 Пушкин көш.,86, Петропавл қ., Қазақстан; e-mail: shaikindimash@mail.ru; https://orcid.org/0000-0001-8922-2803.

Бекматова Ажар Жомартовна; Ph.D докторанты; "Экономика және есеп" кафедрасының оқытушысы; М. Қозыбаев атындағы Солтүстік Қазақстан университеті; 150000 Пушкин көш., 86, Петропавл қ., Қазақстан; e-mail: shaikindimash@mail.ru; https://orcid.org/0000-0002-6437-455X.

\section{Информация об авторах:}

Шайкин Динмухаммед Нурланович - основной автор; кандидат экономических наук, профессор; заведующий кафредрой "Экономика и учёт"; Северо-Казахстанский университет им. М.Козыбаева; 150000 ул. Пушкина, 86, г.Петропавловск, Казахстан; e-mail: shaikindimash@mail.ru; https://orcid.org/0000-0001-7611-2787

Әбутәліп Данияр Оралтайұлы; докторант Ph.D; преподаватель кафедры «Экономика и учет»; Северо-Казахстанский университет им. М.Козыбаева; 150000 ул. Пушкина, 86, г.Петропавловск, Казахстан; e-mail: shaikindimash@mail.ru; https://orcid.org/0000-0001-8922-2803.

Бекматова Ажар Жомартовна; докторант Ph.D; преподаватель кафедры «Экономика и учет»; Северо-Казахстанский университет им. М.Козыбаева; 150000 ул. Пушкина, 86, г.Петропавловск, Казахстан; e-mail: shaikindimash@mail.ru; https://orcid.org/0000-0002-6437-455X. 